Meta

Journal des traducteurs

Translators' Journal

\title{
Ideology and Subtitling: South African Soap Operas
}

\section{Jan-Louis Kruger}

Volume 57, numéro 2, juin 2012

La manipulation de la traduction audiovisuelle

The Manipulation of Audiovisual Translation

URI : https://id.erudit.org/iderudit/1013958ar

DOI : https://doi.org/10.7202/1013958ar

Aller au sommaire du numéro

Éditeur(s)

Les Presses de l’Université de Montréal

ISSN

0026-0452 (imprimé)

1492-1421 (numérique)

Découvrir la revue

Citer cet article

Kruger, J.-L. (2012). Ideology and Subtitling: South African Soap Operas. Meta, 57(2), 496-509. https://doi.org/10.7202/1013958ar

\section{Résumé de l'article}

Le présent article étudie la composante idéologique de l'appui financier au sous-titrage de quatre feuilletons sud-africains : Generations, 7de Laan, Muvhango et Isidingo. Partant des concepts proposés par Lefevere, l'article envisage tout d'abord les différents moyens qui peuvent être utilisés afin de manipuler la traduction audiovisuelle (TAV). L'article montre que cette manipulation résulte du fait que les sous-titres, qui sont constitués par du texte ajouté à l'image lors de la post-édition, masquent une partie de l'écran. Par conséquent, ils sont toujours saillants pour le public. L'article examine ensuite la TAV, plus précisément le sous-titrage, en tant que réécriture. L'accent est mis sur le lien entre langage et idéologie, car celui-ci se rapporte à des questions de pouvoir, liées tout particulièrement au rôle de l'anglais dans les médias, notamment en Afrique du Sud décrite par Gottlieb comme un pays caractérisé par un contexte multilingue anglophile. L'article discute ensuite de la politique linguistique de la Société sud-africaine de radiotélévision (South African Broadcasting Corporation), du point de vue de l'appui financier et de l'idéologie, et poursuit avec le rôle de l'idéologie dans ces quatre feuilletons produits localement. Cette discussion traite des différentes façons dont les pratiques de sous-titrage des feuilletons reflètent l'idéologie. L'article conclut que l'accessibilité joue un rôle moindre que l'idéologie du multilinguisme et du multiculturalisme dans le sous-titrage en Afrique du Sud.
Ce document est protégé par la loi sur le droit d'auteur. L’utilisation des services d’Érudit (y compris la reproduction) est assujettie à sa politique d'utilisation que vous pouvez consulter en ligne.

https://apropos.erudit.org/fr/usagers/politique-dutilisation/ 


\title{
Ideology and Subtitling: South African Soap Operas
}

\author{
JAN-LOUIS KRUGER \\ North-West University, Vanderbijlpark* , South Africa \\ janlouis.kruger@nwu.ac.za
}

\begin{abstract}
RÉSUMÉ
Le présent article étudie la composante idéologique de l'appui financier au sous-titrage de quatre feuilletons sud-africains: Generations, 7de Laan, Muvhango et Isidingo. Partant des concepts proposés par Lefevere, l'article envisage tout d'abord les différents moyens qui peuvent être utilisés afin de manipuler la traduction audiovisuelle (TAV). L'article montre que cette manipulation résulte du fait que les sous-titres, qui sont constitués par du texte ajouté à l'image lors de la post-édition, masquent une partie de l'écran. Par conséquent, ils sont toujours saillants pour le public. L'article examine ensuite la TAV, plus précisément le sous-titrage, en tant que réécriture. L'accent est mis sur le lien entre langage et idéologie, car celui-ci se rapporte à des questions de pouvoir, liées tout particulièrement au rôle de l'anglais dans les médias, notamment en Afrique du Sud décrite par Gottlieb comme un pays caractérisé par un contexte multilingue anglophile. L'article discute ensuite de la politique linguistique de la Société sud-africaine de radiotélévision (South African Broadcasting Corporation), du point de vue de l'appui financier et de l'idéologie, et poursuit avec le rôle de l'idéologie dans ces quatre feuilletons produits localement. Cette discussion traite des différentes façons dont les pratiques de soustitrage des feuilletons reflètent l'idéologie. L'article conclut que l'accessibilité joue un rôle moindre que l'idéologie du multilinguisme et du multiculturalisme dans le sous-titrage en Afrique du Sud.
\end{abstract}

\begin{abstract}
This article investigates the ideological component of patronage in the subtitling of four South African soap operas: Generations, 7de Laan, Muvhango, and Isidingo. Taking the concepts introduced by Lefevere as point of departure, the article first discusses the various ways in which audiovisual translation (AVT) is subject to manipulation. This manipulation is shown to be a result of the fact that subtitles, as text superimposed onto the image during post-editing, thereby obscuring a small part of the screen, constantly foregrounds itself to the audience. This foregrounding is also affected by the linguistic background of the audience - whether or not they understand the original dialogue. The argument then turns to a discussion of AVT, and specifically subtitling, as rewriting. The link between language and ideology is discussed as it pertains to issues of power, particularly related to the role of English in the media, also in South Africa, where, in Gottlieb's terminology, South Africa can be described as a multilingual anglophile context. The language policy of the South African Broadcasting Corporation is then discussed in terms of patronage and ideology followed by a discussion of the role of ideology in these four locally-produced soap operas. In this discussion the different ways in which the subtitling practices of the soap operas reflect ideology are investigated. The article concludes that accessibility plays a smaller role in subtitling in South Africa than the ideology of multilingualism and multiculturalism.
\end{abstract}

\section{MOTS-CLÉS/KEYWORDS}

traduction audiovisuelle, idéologie, multilinguisme, sous-titrage, Afrique du Sud audiovisual translation, ideology, multilingualism, subtitling, South Africa 


\section{Introduction}

Although this article will focus mainly on subtitling, the broader context of AVT with its various forms of manipulation must be sketched briefly. Unlike literary translation, AVT functions on a level where the gaps between source text (ST) and target text (TT) are very much foregrounded - not only through foreignisation as a strategy, but because of the inherent nature of these modes. Any audience is constantly aware of the fact that the text they receive is a mediated text. In fact, one of the pervading questions in audiovisual translation relates to the impact these modes have on the reception of an audiovisual text - how the texts the audiences of these modes actualise differ from the texts actualised by sighted, hearing audiences. The question takes on different nuances depending on the intended target audience.

In none of the major modes of AVT (SDH, AD, interlingual subtitling and dubbing), however, does the target audience of the AVT product constitute the original and primary target audience of the ST.

In the case of subtitling for the Deaf and hard-of-hearing (SDH), the mere fact that a substantial part of the audiovisual text (the entire auditory code) is not available to the target audience directly means that the way the text is activated is necessarily changed substantially - it becomes fully visual. And this is precisely where the concept of manipulation through AVT enters the picture. In this form of AVT the target audience has to rely on an indirect form of access where what was iconic in the ST (iconic sounds as well as nonverbal auditory elements of dialogue) is rendered symbolically in the text of the subtitles (having been changed from nonverbal auditory signs to verbal visual signs in the words of the subtitles).

In the case of interlingual subtitling for audiences who do not understand the language of the original, however, the manipulation is less drastic. Remael (2004: 105) refers to a "homogenizing trend" in subtitling, that is the result of standardisation and subtitling guidelines. At the level of language, then, subtitling may tend to homogenize, or even domesticate. In terms of the semiotics of the mode, however, subtitling is per definition foreignising in that it exists alongside the ST. In the same way, it automatically manipulates the audiovisual text and foreignises the translation. It adds an element to the text that was not there when the audiovisual text was conceived and produced. The ST is not even a palimpsest that shines through, it remains an unaltered (if somewhat curtailed) presence. This quality of subtitling (and AVT in general) sets this form of translation apart from all other forms of translation and even interpreting, where the audience typically only listens to the interpreter and does not rely on the original speech to any significant extent.

According to Nornes (1999: 17), "spectators often find cinema's powerful sense of mimesis muddied by subtitles [...] The original [...] is available to all, but it is easily obscured by the graphic text through which we necessarily approach it." But, as Szarkowska (2005) says, "subtitling contributes to experiencing the authentic flavour of the foreign language, its mood and the sense of a different culture more than any other translation mode - the audience is not allowed to forget about the foreignness of a translated film." According to Szarkowska (2005), "subtitling can be considered part of the foreignisation realm: the crucial role of the source culture is stressed, foreign identity highlighted and the influence of the target culture minimised." 
Against the overwhelming landscape of possible manipulations in AVT, this article will focus only on the ideological factors that influence and manipulate the production of interlingual subtitling (and to some extent SDH) in a very specific context, namely that of South African soap operas broadcast on the three channels of the South African Broadcasting Corporation (SABC). The soap operas in question are Generations (1994 -; broadcast by SABC1), ${ }^{1} 7$ de Laan $(2000$-; broadcast by SABC2), ${ }^{2}$ Muvhango (1997 -; broadcast by SABC2) ${ }^{3}$ and Isidingo (1998 -; broadcast by SABC3). ${ }^{4}$

The article takes as broad point of departure the concepts introduced by Lefevere (1992) in his Translation, Rewriting, and the Manipulation of Literary Fame. Although Lefevere writes about the translation of literature, the concept of patronage, with its ideological, economic and status components, seems to be relevant to an understanding of subtitling practices in South Africa.

\section{Translation as rewriting}

Lefevere (1992: 2) investigates issues related to the context in which rewriting takes place and is received, including "power, ideology, institution and manipulation." Although he focuses on the rewriting of literature, often involving large differences in time, culture, and location of ST and TT, I believe that the factors he identifies also apply to AVT, and in particular in contexts such as South Africa where decisions on what should be subtitled, and into which languages, tend to be determined by power relations and ideology on the one hand, and by economic and institutional factors on the other. In the context of the rewriting of literature, Lefevere states the following:

Rewriters and rewritings project images of the original work, author, literature, or culture that often impact many more readers than the original does. Rewritings [...] often conclusively shape the reception of a work, an author, a literature, or a society in a culture different from its culture of origin. Lefevere (1992: 110)

The above statement has direct bearing on the rewriting that occurs in AVT. The main difference between the rewriting of literature and the rewriting of audiovisual texts is of course that AVT never rewrites fully, with the possible exception of remakes of texts that have been subject to AVT previously. Any target audience of AVT receives the partial rewriting through AVT simultaneously with part of the ST, which is never replaced fully. What this implies is that the audience is aware that part of the text is a rewriting, and that they have to integrate this with that part of the text which is still available to them. In the case of interlingual subtitling in particular, the audience has access to both the full ST and the rewriting of the dialogue, and in multilingual communities like South Africa, this means that at least part of the audience will be able to compare the ST to the TT.

Lefevere (1992) identifies three main factors that control the literary system in which translation occurs, namely professionals in the literary system, patronage outside the literary system, and the dominant poetics. I would like to isolate his second factor as the one most obviously applicable to AVT, and that will be elaborated upon in this article, namely patronage outside the literary system that consists of those "powers (persons, institutions) that can further or hinder the reading, writing, and rewriting of literature" (Lefevere 1992: 15). The three components that make up 
patronage are identified as the ideological, economic, and status components, and I would once again like to focus in on only one of these, namely ideology.

According to Munday (2008: 127), the most important consideration for Lefevere is the ideological dimension, "which in this case refers to the translator's ideology, or the ideology imposed upon the translator by patronage." Thus, Lefevere (1992: 16) states that ideology "acts as a constraint on the choice and development of both form and subject matter." Furthermore, he states that ideology is taken in a sense not limited to the political sphere but rather, "[i]deology would seem to be that grillwork of form, convention, and belief which orders our actions" (Jameson 1974: 107, in Lefevere 1992: 16). What this implies for subtitling, is that ideological factors will determine which programmes are subtitled, for which target audience, into which languages, and in which way. This seems somewhat self-evident, but in a context such as South Africa, where the volume of locally-produced content is determined by the $\mathrm{SABC}$, that acts as a patron, commissioning programming that have to meet specific requirements in terms of content, language and style, patronage becomes a very real constraint on subtitling. The SABC could be considered, in Lefevere's terms (1992: 17), as an example of undifferentiated patronage in that the three components of patronage, namely the ideological, economic and status components are all dispensed by the SABC. It provides the ideological parameters, determines (albeit indirectly) what subtitlers are paid, and also what status these translations will have.

According to Lefevere,

[a]cceptance of patronage implies that writers and rewriters [and we could add subtitlers] work within the parameters set by their patrons and that they should be willing and able to legitimize both the status and the power of those patrons as attested most forcibly, for instance, by the African praise song, a collection of honorific epithets commemorating and celebrating the patron's great and noble deeds. (Lefevere 1992: 18)

Since the SABC is less of an obvious patron in the conventional sense (and it tends to do its own "praise songs"), producers of programming have to ensure that they display the image of the broadcaster as multicultural, multilingual, unbiased, and nation building.

Although the political dimension of ideology is underplayed in Lefevere's theory, it remains an important component, particularly in the context of AVT in South Africa with its eleven official languages. In the next section I will elaborate on the role of ideology and language.

Asimakoulas (2008: 242) suggests that "Lefevere's theory of rewriting attempts to incorporate a wide range of complex factors in an essentially flat model" which renders it superficial. I realise that the application of this theory to AVT has the potential to make this deficiency even more acute, especially in view of the fact that subtitling, more than $\mathrm{AD}$, is hardly rewriting in any sense approaching the way Lefevere uses the concept. Nevertheless, in the system of audiovisual texts, his broad notions provide a useful starting point from which to investigate the factors that play a role in the manipulation of these texts. "Despite its limitations," Asimakoulas (2008: 244) writes, "Lefevere's model has been instrumental in situating translation within a broader set of activities to which it is inextricably linked, and in drawing researchers' attention to social and institutional factors that influence all processes of rewriting." Lefevere's model is appealing, according to Asimakoulas (2008), precisely 
because "it identifies important contextual factors that impinge on translation, irrespective of how well it weaves these factors into a coherent model." In Asimakoulas' opinion,

the way in which these factors operate, and the promotion of political and other interests through translation, are not restricted to the area of literature (Lefevere's main preoccupation). The same can be said to apply to other types of translation and to polymedial products such as advertising material, audiovisual material, and comics. (Asimakoulas 2008: 244-245)

\section{Language and ideology}

“Questions of language," says Chomsky (1979: 191), "are basically questions of power." And this power resides, in the case of AVT as in the case of literary translation, primarily in the patronage of the literary (and media) system. In the South African linguistic landscape, the fact that eleven languages have been awarded official status in the Constitution, does not necessarily translate into equal status. In reality, as in many other previously colonised countries, this power still resides in a colonial language, in this case English. Although one of the official languages, English is only spoken as mother tongue by around $8 \%$ of the population, making it only the sixth largest mother tongue (Kruger, Kruger et al. 2007: 43). Yet, in most spheres from education (where English is the dominant language at all levels), to government and to the media, English has ideological currency not equalled by any other official language.

In his article Language planning and politics in South Africa, Webb (1996: 140) provides a useful overview of the role of language in South African history, and in particular, he states that the "language knowledge of South Africans is inadequate as a resource for nation-building." He puts this quite strongly:

The linguistic competence of South Africans does not allow effective intergroup communication. According to the 1991 census survey 49 percent of the country's population

"know" English and 44 percent "know" Afrikaans. Other surveys, however, suggest that 80 percent of the country's population do not know either language sufficiently well to be able to conduct a conversation at a reasonably complex level. (Webb 1996: 140)

The perception that the majority of the population is proficient in English, has to be questioned, especially in view of a sociolinguistic survey conducted in 2001 for the Pan South African Language Board (PanSALB) which indicated that a mere $22 \%$ of non-English-speaking South Africans feel they are fully proficient in English to the degree that allows them full access to speeches and statements in English, while a further $27 \%$ feel that they understand only as much as they need to. The results suggest that "communication of political, policy and administrative information in South Africa is generally only adequately understood by half the non-English-speaking population" (PanSALB 2001: 9). These findings confirm Webb's statements above. Although this survey is already ten years old, and much may have changed in the past decade, the reality remains that the dominance of English is not in line with the ideals of the Constitution.

The dominant position of English is, of course, not unique to South Africa. According to Bassnett and Trivedi (1999: 13), similar power relationships are played out between various local languages and what they call the one "master-language of our post-colonial world, English.” In terms of the ideological component of Lefevere's 
(1992: 16) factor of patronage, it should be clear that the choice of presentation of programming in terms of language, namely making everything available in English, has a significant impact on subtitling in South Africa.

Gottlieb (2004) discusses the dominance of Anglophone media (primarily through imports of programming from the United States of America) across the globe. In South Africa the situation is no different, and the dominance of Anglophone media is further supported by the local production of English language programming, as well as the current SABC policy of subtitling most local programming in languages other than English, into English. Gottlieb (2004: 94-95) outlines six scenarios regarding programme exchange and screen translation choices on TV arranged on a continuum from the cosmopolitan situation (Utopian scenario), to the monolingual anglophile situation (Scandinavian scenario), the multilingual anglophile situation (South African scenario), the monolingual nationalist situation (French scenario), the Anglophone situation (what he calls the "Anglostan" scenario in English-speaking countries), to the anglified situation (Dystopian scenario). The multilingual anglophile situation in South Africa includes massive programme imports, a predominance of English programming, and mainly indigenous programmes being subtitled into English.

Before turning to the language situation in specific programmes on SABC TV, the general language-political situation at the SABC will now be discussed in order to explain the ideological factors that impact on subtitling choices in these programmes.

\section{The SABC and language}

The South African Broadcasting Act of 1999 stipulates, among other things, that the SABC must:

a) make services available to South Africans in all official languages;

b) reflect both the diversity and the unique cultural and multilingual nature of South Africa and all of its cultures and regions to audiences;

c) strive to be of high quality in all of the languages served... (Republic of South Africa Government 1999: 13)

The SABC (2005: 2) ${ }^{6}$ maintains in its language policy that, "as South Africa's public broadcaster, the SABC embraces the constitutional duty to treat all the official languages equitably, and with equal respect." According to the South African Constitution, "[r]ecognising the historically diminished use and status of the indigenous languages of our people, the state must take practical and positive measures to elevate the status and advance the use of these languages" (Republic of South Africa Government 1996: 1245).?

This is reflected in the SABC language policy which states that its aims and objectives are to:

- inform, educate and entertain South Africans in their home languages;

- promote understanding and acceptance of and between the linguistic and cultural groups in South Africa;

- contribute to the continual development of the 11 official languages and South African sign languages;

- promote multilingualism in South Africa. (SABC 2005: 2, see note 6) 
The SABC has made progress in terms of the visibility of the different official languages by introducing daily news bulletins on two of its three channels, SABC1 and SABC2, in the ten official languages other than English, and also by commissioning locally-produced dramas, magazine programmes, current affairs programmes and soap operas reflecting the multilingual society. ${ }^{8}$ Soap operas are probably the most important tool in this regard because of their sustained nature, and the fact that they tend to become such a part of the lives of those who follow them. According to Marx:

The use of multiple languages makes the soap operas [7de Laan, Generations and Isidingo, among others] accessible to a larger audience and gives audiences the opportunity to interact with different cultures and languages, in this way deconstructing existing language identities and broadening the scope of potential viewers [...] Soap operas thus contribute to a national unity (and a subsequent embracing of the national complexity) or a kind of South African identity that forms part of the multiplicity of identities within the South African context. (Marx 2007: 117)

From the language policy of the SABC as well as the prime-time scheduling on mainly SABC1 and SABC2, it is clear that these two channels in particular do provide substantial programming in official languages other than English; they do promote, or attempt to promote, intercultural understanding; they do, to some extent, contribute to the development of all official languages; and, if using more than one language in a programme can be taken as a yardstick, they do promote multilingualism. Unfortunately this ideological aim is far from simple, and what may appear to be in compliance with the policy on the surface, finds very different implementation in different programmes. For one, the policy of subtitling only into English robs the other languages of the obvious benefits subtitling would hold for the promotion of these languages, and it propagates the erroneous assumption that all South Africans have access to English, in the process privileging English at the cost of the other languages.

I do not want to suggest that the ideological component of patronage is a straightforward affair in the case of subtitling on SABC TV. Obviously there are also economic considerations, namely that the higher income groups tend to be more educated, and therefore tend to be more proficient in English, a fact that would carry a lot of weight in terms of advertising revenue. As in any other context, each genre, and each individual programme within that genre, will be subject to both generic and unique constraints, also related to ideology. In order to illustrate this, I will now turn to a discussion of four of the locally-produced soap operas on SABC TV. 


\section{Ideology, manipulation and the subtitling of soap operas on SABC}

Table 1 provides an overview of the soap operas that are currently broadcast on SABC channels.

TABLE 1

Soap operas on SABC

\begin{tabular}{|l|l|l|l|l|}
\hline Soap Opera & Channel & Times & Languages & Subtitles \\
\hline Generations & SABC1 & $\begin{array}{l}\text { Weekdays 20:00 to 20:30; } \\
\text { Morning repeats; } \\
\text { Omnibus Saturday } \\
\text { SABC1\&3 }\end{array}$ & $\begin{array}{l}\text { Multilingual (mainly } \\
\text { Zulu, Xhosa and } \\
\text { Southern Sotho, } \\
\text { Tswana) }\end{array}$ & $\begin{array}{l}\text { English subtitles } \\
\text { exclusively when the } \\
\text { dialogue is not in } \\
\text { English. }\end{array}$ \\
\hline 7de Laan & SABC2 & $\begin{array}{l}\text { Weekdays 18:30-19:00; } \\
\text { Afternoon repeats; } \\
\text { SABC2 } \\
\text { SABC3 }\end{array}$ & $\begin{array}{l}\text { Mainly Afrikaans, but } \\
\text { Omnibus Sunday } \\
\text { afternoons } \\
\text { Sotho, and Zulu. }\end{array}$ & $\begin{array}{l}\text { Full English } \\
\text { subtitles }\end{array}$ \\
\hline Muvhango & SABC2 & $\begin{array}{l}\text { Monday to Thursday } \\
\text { 21:00-21:30; } \\
\text { Afternoon repeats; } \\
\text { Sorning repeats; } \\
\text { Omnibus Saturday } \\
\text { SABC2 }\end{array}$ & $\begin{array}{l}\text { Multilingual, with } \\
\text { Southern Sotho, } \\
\text { English, Venda, Zulu } \\
\text { and Xhosa }\end{array}$ & $\begin{array}{l}\text { Full English } \\
\text { subtitles }\end{array}$ \\
\hline Isidingo & SABC3 & $\begin{array}{l}\text { Weekdays 18:30-19:00 } \\
\text { Morning repeats; } \\
\text { Omnibus Sunday } \\
\text { mornings }\end{array}$ & $\begin{array}{l}\text { Mainly English with } \\
\text { Afrikaans, Zulu and } \\
\text { Sotho }\end{array}$ & $\begin{array}{l}\text { English subtitles } \\
\text { exclusively when the } \\
\text { dialogue is not in } \\
\text { English. }\end{array}$ \\
\hline
\end{tabular}

According to Marx (2007: 127), "the use of multiple languages makes the soap operas accessible to a larger audience and gives audiences the opportunity to interact with different cultures and languages, in this way deconstructing existing language identities and broadening the scope of potential viewers." Nevertheless, the one aspect that stands out in the above, is that all the subtitling is done only into English (sometimes also same language subtitling from English, but mostly from one of the other official languages). In fact, the SABC has been maintaining this unwritten policy of subtitling only non-English content into English for more than a decade now.

\subsection{Generations}

The target market for $\mathrm{SABC} 1$, according to its website, ${ }^{10}$ is predominantly between the ages of 16 and 34. All the top 5 programmes on SABC, in terms of highest viewership, are on this channel, with Generations topping the list. According to Motsaathebe (2009: 431-432), Generations premiered on SABC1 in 1994, making it the longestrunning soap opera on SABC, and "reflects strongly on the demographics of the new South Africa." This soap opera makes use of English subtitles exclusively for dialogue that is not in English. This means that in a sentence that starts off in English and then shifts to another language (i.e., using code switching), only that part of the sentence that is not in English will be subtitled. This has the effect of forcing the audience to constantly shift from processing verbal-auditory code (spoken dialogue) to processing verbal-visual code (subtitles). Exactly what impact this code switching has on the processing of the programme as a whole has not, to my knowledge, been tested 
empirically, but it stands to reason that this practice places an added cognitive load on the audience, which may leave less capacity for processing the remaining visual and auditory codes.

According to Msimang, the percentage of dialogue that is subtitled on Generations

[...] has risen from very little subtitling at its inception in 1994, to up to 60 per cent at present according to Matseoane [in an interview conducted by Msimang in 2006 with Matseoane in his capacity as head translator of the programme]. The figure is still rising and ICASA (Independent Communications Authority of South Africa), which enforces the promotion of multilingualism in the media, requires it to be at 75 per cent by March 2007. (Msimang 2006: 9)

Although updated information on the current percentage of subtitling could not be found for this paper, the above-mentioned practice of subtitling has persisted.

More importantly, the non-English dialogue does not start out as such in the script. According to Msimang (2006: 17), the use of English in Generations creates an imbalance, particularly since the script is written in English, and the phrases and sentences that are delivered in other languages are only translated into those languages at a later stage, before being translated back into English for the English-only subtitles. Furthermore, Msimang (2006: 19) indicates that "the choice of what is translated into languages other than English seems to be arbitrary, and what gets translated is simply what is [deemed] translatable." In his study, Msimang (2006) provides a detailed analysis of linguistic manipulation in the subtitles ranging from reduction, to literal translation, and the translation of sociolect into standard English.

It would therefore appear that the main ideological component in the manipulation of subtitling in Generations involves the ideological dominance of English. However, the patronage of this soap opera also involves the target audience. In this regard, Msimang (2006: 15) states that: "[t]he characters in Generations reflect the transforming South African society, as the black bourgeoisie is becoming more and more entrenched. It reflects the changing South Africa and the realities of the country today. Generations seeks to portray the emerging rich black people."

This element of patronage therefore supports the ideological position of the SABC on the use of English, since the target audience is also that part of the South African population that prefers English as the medium of education. However, the fact that English is by no means understood by the majority of South Africans would suggest that this manipulation may not serve the interests of the target audience in terms of access to entertainment.

\subsection{7de Laan}

The situation in the only Afrikaans-language soap opera on SABC, 7de Laan (on air since 2000), is strikingly different, although some of the ideological elements of patronage remain. As in Generations, subtitling only occurs into English, but unlike Generations, all dialogue is subtitled, including English dialogue. In this soap opera, the dialogue is predominantly in Afrikaans, but with some isolated English, Zulu, Sotho and Xhosa dialogue, all subtitled into English. Milton (2008: 267) ascribes the popularity of the show among "South Africans from all spheres and groups" to this multilingual profile of the programme. Furthermore, although the programme does not contain SDH, some sound effects are subtitled. The fact that all dialogue is 
subtitled into English, regardless of the language, combined with the addition of some $\mathrm{SDH}$ elements, does mean that this is one of the very few programmes on SABC that is accessible to Deaf and hard-of-hearing viewers.

Whereas Generations "seeks to portray the emerging rich black people" (Msimang 2006: 15), 7de Laan portrays an urban community populated largely by Afrikaansspeaking characters (white, black and coloured) from all walks of life. According to Milton (2008: 261), this soap opera targets a multicultural audience, and contributes to the nation-building project in South Africa. However, Milton (2008: 261) remarks that "[j] ust who the nation is that the SABC wishes to build through this channel, is a matter for analysis." In terms of the dominant ideology, Milton (2008: 263) further states that: "7de Laan is a soap opera that, up to a point, presents a liberal-pluralist utopia of 'the nation in colour.' It presents utopian images of community, workingclass and ethnic solidarity, and personal friendship without necessarily interrogating what the impact of an alternative society might be."

The same utopian image is portrayed in the Afrikaans dialogue, with most characters speaking a standard Afrikaans, with very little in the way of sociolect, in spite of the fact that, in reality, there are significant differences in the way different population groups speak the language. This standardisation of the main language serves the ideological purpose of removing cultural and linguistic markers that differentiate between people, thereby strengthening the nation-building project.

Since subtitling already tends to homogenise (Remael 2004: 105), this standardisation of the dialogue is homogenised even further in the subtitles, where all characters come to "be read" similarly - markers of characterisation, ethnicity, social standing, etc. largely disappear.

In terms of Lefevere's ideological component of patronage, 7de Laan is a clear instance of the promotion of the post-apartheid ideology of the "rainbow nation." The fact that the programme is mainly in the erstwhile language of the oppressor, explains the attempts to present a utopian community that is largely homogenous, with roughly equal numbers of white and black and coloured characters, all proficient in Afrikaans.

At the same time the patronage of the white Afrikaner viewership, which still constitutes the most economically powerful part of the overall viewership, acts as a constraint on the form and subject matter of the soap opera. This audience could be characterised as carrying a residual conservatism reflected in gender if not in race as well as in the use of language in the dialogue. What the subtitles do, is to manipulate and obscure this element, thereby rendering the soap opera more palatable to the viewers who do not follow Afrikaans, an impression that is strengthened by the scattering of SDH elements.

\subsection{Muvhango}

Muvhango is an important example of the SABC's attempt to provide equitable language representation as it is the only soap opera to contain a large percentage of Venda, the second smallest official language and therefore one of the most marginalised (Kruger, Kruger et al. 2007: 43). It has been on air since 1997 and actively presents a social commentary on the South African cultural landscape with a Venda content and Sotho bias, according to Mutsila (in a personal interview by Mbhulumeti 
[2006]), the language and cultural advisor of the programme. The programme's alternation between the rural setting in the far north of South Africa's Limpopo province, and the urbanised setting of Johannesburg, provides a unique insight into complex cultural dynamics. The dominant language of the programme is Southern Sotho, but a significant percentage of the dialogue is in Venda, with limited use of Zulu, English and Xhosa - making it the soap opera with the biggest representation of languages other than English.

The content as well as the language use in Muvhango means that, as in the case of the three other locally-produced soap operas, it supports the ideological aim of nation building by portraying the multilingual and multicultural reality of the country. The utopian element present in 7 de Laan is less pronounced, although rural vs. urban stereotypes also reflect an idealised, or at least artificial, reflection of social reality.

In terms of the ideological component of patronage, Muvhango achieves an interesting combination of aims by promoting "understanding and acceptance of and between the linguistic and cultural groups in South Africa" and "multilingualism in South Africa" as set out in the SABC language policy (2005: 2; see note 6). It does this by providing a window on the culture of rural speakers of Venda as well as that of urban speakers of Venda and Southern Sotho, as one of the larger languages in a context where Venda is even more marginalised, making the material accessible to the latter as well as to that part of the audience that does not speak either of the languages through subtitling of all the dialogue into English.

\subsection{Isidingo}

Whereas Generations and Muvhango mainly feature black characters in an urban or rural and urban setting respectively, and 7de Laan features a mixed cast speaking mainly Afrikaans, Isidingo has a mixed cast with white characters speaking mainly English with some Afrikaans, and black characters speaking mainly English, with some Zulu and Southern Sotho. It premiered in July 1998 on SABC3 and, according to Barnard (2006: 45), "it infuses politics into its narratives as it follows the business, political and personal fortunes of a large group of multiracial characters associated with the gold mine Horizon Deep near Johannesburg, and their lovers, friends and relatives."

Barnard (2006: 49) argues that in Isidingo, "the explicit conceptualisation of language as a political tool and a tool of politics is a reflection of both the long and formative history of language politics in South Africa and the new South African constitution's attention to linguistic equity." This conscious use of language in the service of the ideology of multilingualism once again confirms the role of this component of ideology in the patronage of subtitling on SABC TV, while providing yet another view on the complex multicultural society in the country.

I would argue that this soap opera in particular reflects the interaction between the different classes in society from mine workers to housewives and to mine bosses where culture, race and language add a unique dynamic that is less simplistic and idealised than on, for example, Muvhango and 7de Laan. Like Generations, it reflects the changing social reality, but through its subject matter it provides a more balanced picture of an urban environment where class is fast becoming more dominant than race in the economic powerhouse of the region. 
Although Isidingo follows the same practice as Generations by only subtitling those parts of sentences that are not in English, the fact that the dialogue is predominantly in English, combined with the fact that it is aired on SABC3 which is almost exclusively an English-language channel (presumably also with an audience that is more proficient in English than, for example, on SABC1), makes the dual processing of aural and written verbal codes less demanding. Nevertheless, the mere fact that English dominates both dialogue and subtitling is a clear indication that the ideological component of patronage which considers English to be the one language that cuts across all societies, once again results in a manipulation of the social and linguistic reality in the country.

\section{Conclusion}

Subtitling in South Africa, unlike in most other countries, is not primarily about access. The fact that, in the four soap operas that were discussed, all dialogue that is not in English is translated into English, makes it obvious that the ideological component (like the economic and status components) of patronage outside the audiovisual system, controls the system within which subtitling operates. This is particularly clear against the background of the linguistic reality where the general proficiency in English of the population appears to be overestimated.

At the same time, the target audience is diverse and complex. This is further complicated by the fact that subtitling of popular television in South Africa, unlike the translation of literature, has to accommodate the needs of both a ST audience that understands both English and the other languages spoken in a given text, and a target audience that does not understand any or only understands some of the other languages, and therefore relies on the English subtitles.

In Generations, aimed primarily at black viewers between 16 and 34, the audience would presumably understand the indigenous languages and some degree of English, making the processing of the code switching difficult, especially when a subtitled fragment is on screen after a shot change simultaneously with the rest of the sentence which is in English.

7 de Laan works with one audience segment (the dominant one) that is almost bilingual and can access and compare both dialogue and subtitles, and with another target audience that has a low proficiency in Afrikaans and varying proficiency in English for whom the subtitles provide access.

In other words, in South Africa the use of subtitling becomes more of an ideological tool - not only informed by ideology, but promoting multilingualism and multiculturalism. In the utopian world of South African soap operas, everyone is multilingual. Yet, through the monolinguistic subtitling policy, all characters come to speak English, more or less fluently. This warped reality has a very specific ideological goal, namely projecting, promoting and sustaining the notion that people from all walks of life are proficient in English. More specifically, the multicultural nature and intricate characterisation that occurs through language is consistently negated, or at the very least neutralised, in subtitles where everyone speaks the same English.

The context of SA therefore calls for an approach to subtitling that is aware of this multilayered cultural and linguistic context. Unfortunately, until the SABC 
revises its policy of subtitling only into English, the SABC as patron of subtitling will not be able to arrive fully at its aims of multilingualism, multiculturalism and the promotion of all the official languages.

In much of my argument it becomes clear that further research is required on the reception of multilingual soap operas/programming in South Africa, not only in terms of preferences and attitudes, but also in terms of the way in which representative audiences process subtitles together with dialogue they only understand partially.

\section{NOTES}

* Vaal Triangle Campus.

1. Generations (1994 -): Directed by Mfundi Vundla and Friedrich Stark. Broadcast by SABC1. Johannesburg: Morula Pictures.

2. 7de Laan (2000 -): Directed by Danie OdendaAl. Broadcast by SABC2. Johannesburg: Danie Odendaal Produksies.

3. Muvhango (1997 -): Directed by Duma NdLovu. Broadcast by SABC2. Johannesburg: Word of Mouth Productions.

4. Isidingo (1998 -): Directed by Will Grey Hofmeyr. Broadcast by SABC3. Johannesburg: Endemol South Africa.

5. REPUBLIC OF SOUTH AFRICA GOVERNMENT (23 April 1999): Broadcasting Act (4 of 1999). Pretoria: Government Printers. Visited on 30 June 2012, <http://www.info.gov.za/view/ DownloadFileAction?id=70607>.

6. SABC (2005): Language. Visited on 30 June 2012, <http://vcmstatic.sabc.co.za/VCMStaticProdStage/ CORPORATE/SABC\%20Corporate/Document/About\%20SABC/Legislative\%20\&\%20Regulatory $\% 20$ Organs/language.pdf $>$.

7. REPUBLIC OF SOUTH AFRICA GOVERNMENT (18 December 1996): Constitution of the Republic of South Africa - N 108 of 1996. Pretoria: Government Printer. Visited on 30 June 2012, $<$ http://www.info.gov.za/documents/constitution/1996/a108-96.pdf>.

8. SABC1 caters mainly for official languages from the Nguni family (Zulu, Xhosa, Ndebele, Swati); SABC2 for languages from the Sotho family (Southern Sotho, Northern Sotho/Pedi, Tswana), Venda and Tsonga that do not belong to a bigger family, and Afrikaans; SABC3 caters mainly for English.

9. Information on exactly which languages are spoken in these programmes is very hard to come by, so this information may not always be $100 \%$ correct. Nevertheless, the situation in reality would not be too different, with small quantities of Tswana, Pedi, and minority languages being spoken from time to time.

10. SABC (Last update: 2012): Who are we? SABC1 Website. Visited on 30 June 2012, <http://www. sabcl.co.za/index.php/about-us>.

\section{REFERENCES}

Asimakoulas, Dimitri (2008): Rewriting. In: Mona Baker and Gabriela Saldanha, eds. Routledge Encyclopedia of Translation Studies. London: Routledge, 241-245.

Barnard, Ian (2006): The language of multiculturalism in South African soaps and sitcoms. Journal of Multicultural Discourses. 1(1):39-59.

Bassnett, Susan and Trivedi, Harish, eds. (1999): Post-Colonial Translation: Theory and Practice. London: Routledge.

Сномsку, Noam (1979): Language and Responsibility. London: Harvester.

Gottlieb, Henrik (2004): Language-political implications of subtitling. In: Pilar Orero, ed. Topics in Audiovisual Translation. Amsterdam/Philadelphia: John Benjamins, 83-100.

Kruger, Jan-Louis, Kruger, Haidee and Verhoef, Marlene (2007): Subtitling and the promotion of multilingualism: the case of marginalised languages in South Africa. Linguistica Antverpiensa. 6:35-50.

Lefevere, André (1992): Translation, Rewriting, and the Manipulation of Literary Fame. London: Routledge. 
Marx, Hannelie (2007): Narrative and Soap Opera: A Study of Selected South African Soap Operas. Master's dissertation, unpublished. Pretoria: University of Pretoria.

Mвнulumeti, Morgan (2006): Audience Needs and the Subtitling of Muvhango. B.A. Honours research project, unpublished. Vanderbijlpark: North-West University.

Milton, Viola Candice (2008): 'Local is lekker': Nation, narration and the SABC's Afrikaans programmes. Communication. 34(2):255-277.

Motsaаthebe, Gilbert (2009). Gendered roles, images and behavioural patterns in the soap opera Generations. Journal of African Media Studies. 1(3):429-448.

Msimang, Violet Busisiwe (2006): Subtitling Practices in South Africa: A Case Study of the Soap Opera Generations. Master's dissertation, unpublished. Johannesburg: University of the Witwatersrand.

Munday, Jeremy (2008): Introducing Translation Studies. London: Routledge.

Nornes, Abé Mark (1999): For an abusive subtitling. Film Quarterly. 52(3):17-34.

PanSaLB (PAN SOUTH AFRICAN LANGUAGE BOARD) (2001): Guidelines for Language Planning and Policy Development: Language Use and Language Interaction in South Africa. PanSALB Occasional Paper Series. 6. Pretoria: PanSALB.

Remael, Aline (2004): A place for film dialogue analysis in subtitling courses. In: Pilar Orero, ed. Topics in Audiovisual Translation. Amsterdam/Philadelphia: John Benjamins, 103-126.

Szarkowska, Agnieszka (2005): The power of film translation. Translation Journal. 9(2). Visited on 30 June 2012, <http://translationjournal.net/journal/32film.htm>.

Wевв, Victor (1996): Language planning and politics in South Africa. International Journal for the Sociology of Language. 118(1):139-162. 